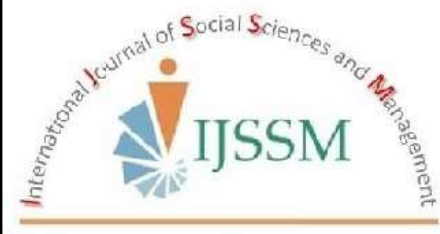

International Journal of Social Sciences and Management

\author{
Research Article
}

\title{
Knowledge and Attitude Regarding Hepatitis-B Prevention among People of Lahore Community, Pakistan
}

\author{
Asaf Khan*, Muhammad Ali and Rafiullah \\ The University of Lahore, Pakistan \\ *Corresponding author email: Asafkhan.akk@gmail.com
}

\begin{abstract}
s
Hepatitis-B is a communicable disease and globally a public health problem with a complicated pathology of liver, which disturbs the normal function of the liver caused by Hepatitis-B virus known as HBV. This study aims to determine knowledge and attitude regarding Hepatitis-B prevention among people of Lahore community, Pakistan. Cross-sectional survey technique was used in current study. The self-administered questionnaire distributed to the 200 participants through convenient random sampling. Descriptive analysis was used to analyze the data using SPSS (statistical package for social science studies) version 21.The findings of the current study showed, poor knowledge and negative attitude of the participants toward prevention and treatment of Hepatitis-B in the community of Lahore, Pakistan. Moreover they were preferred home remedies, complementary therapies and spiritual healers as compared to medical treatment.
\end{abstract}

Keywords: Knowledge; Attitude; Hepatitis B; prevention

\section{Introduction}

Hepatitis-B is a severe, thoughtful and communicable disease with a complicated pathology of liver which disturbs the normal function of the liver caused by Hepatitis-B virus known as HBV and with the passage of time the seriousness and the complication of disease progressively increases, which is furthermore become a concerning point for medical profession as well as for those who have lack of knowledge especially in developing countries (Ozaras, 2009).

Prior its causing and spreading it could be prevented through knowledge and modification of attitude towards Hepatitis-B prevention because globally this disease is considered one of the community problem among people, therefore its mortality rate is high (Singhal et al., 2009). Moreover its spreading is gradually enhancing and become a concerning disease globally and also in some regions in Pakistan, where people are unaware about its causes, transmission and prevention (Ali, 2011).

The Hepatitis-B virus can be detected with contact to infected person's blood, serum, and bodily fluids (McCarthy, 2000). According to Bello et al. (2012) emphasized that the proportion of this disease which is transmitted from mother to fetus and sexual transmission is higher in developing countries as compare to developed countries due to lack of knowledge and the disposition (attitude) toward irrelevant treatment e.g. (spiritual healers, ayruvadic and homeopathic etc.) among the people. According to WHO billions of persons are affected between twenty and forty years of age due to Hepatitis-B worldwide with high rate in developing countries (WHO, 2000).

Chang (2009) stated that, four hundred people are dying every year due to Hepatitis-B with respect of poor knowledge (lack of awareness) and specific behavior toward this disease. This high prevalence rate shows that, it has great importance to prevent it worldwide and especially from that rural regions in developing countries where people did not know about it (Ali, 2011). The occurrence in regards to Hepatitis-B disease will be around non-stop rise in Pakistan as well as the spreading for Hepatitis-B ranges the middle of seven to twenty percent in Pakistan public and varies from local to area (Kumar, 2010). Pakistan may be arranged as a local from 
demanding 'intermediate risk' towards Hepatitis-B near WHO (WHO, 2000).

Knowledge is the first priority toward prevention of Hepatitis-B because many population where knowledge is deficit are susceptible to get hepatitis B. Centre for Disease Control (2010) elaborated that "many persons who has been infected don't know that they are infected because it silently damage the liver function which takes time up to 30 years to develop but don't show any sign or symptoms (CDC, 2010). Lack of knowledge which may be lead to a fatal condition due to this infectious and contagious disease, so poor knowledge could be enhanced after a thorough study to prevent it, especially in the rural areas where knowledge is deficit, as Haq (2012) highlighted that knowledge is proportional to any disease, if the knowledge become deficit the prevalence rate will be increased.

Ali et al. (2011) emphasized that nursing care has been rotated from Health Belief model in which the belief, attitude and value are greatly respected in term of treatment as well as caring for a client. According to a study on attitude which was completed in the Quetta Pakistan, which is a rural area, almost resident of that area were independently evaluated their health status, whenever they felt any illness, the evaluation of their attitude and values indicated that mostly people were favoring to concern with yunani, avrovedic and spiritual healers instead of medical treatment which create a complicated waves in their lives because of irrational and irrelevant information as well as treatment, which further more confused them what treatment should be adapted in term of treatment even their disease were in last stage and in severe form accordingly. Another concerning point about this study is that, most of centers among these were still not registered by government or affiliated with any board (Haq, 2012)

The above discussion clearly shows the goal and purpose of this study to identify the knowledge and attitudes regarding prevention of Hepatitis-B infections, among people of Lahore community and the expected outcomes of this study would be the way to take some therapeutic interventions after full filling this research about HepatitisB prevention.

\section{Variables}

Knowledge and Attitude were dependent variables which was determined among the people of Lahore community and Hepatitis-B prevention was the independent variable in this study.

\section{Problem Statement}

Pakistan is considered as one of the developing country, which is categorized as intermediate risk country by world health organization for Hepatitis-B infection, especially in rural region (WHO, 2009). So the community of Lahore (Ali Raza Abad) is one of the rural area having positive and known cases of Hepatitis-B were observed and also having low illiteracy rate of the people, therefore it was quite important to be studied on this aspect to determine knowledge and attitude of the people with respect of what they know and believe with the help of this study.

\section{Significance of the Study}

The study findings assist the stake holders of the community to know the importance of vaccination of Hepatitis-B and also help the Government/Institutes and NGO's to develop the strategies to enhance the knowledge regarding $\mathrm{HBV}$ vaccination among the society to decrease the mortality and morbidity rate from the disease. Furthermore, the study findings increased the awareness among the societies regarding preventive measures of diseases and help the policy makers in the identification of the societies which are affected by Hepatitis B. Similarly, the study finding shaped the positive attitude of the society member towards the prevention of the Hepatitis B. Thus, the current study had been helpful to enhance the knowledge and make their positive attitude towards the prevention of infection of Hepatitis-B vaccination.

\section{Research Questions}

1. Do people have knowledge regarding Hepatitis-B prevention?

2. What are the attitudes "around people toward the Hepatitis-B prevention?

\section{Objectives}

1. To determine the prevention knowledge of Hepatitis-B among community's people

2. To know about attitude of the people toward Hepatitis-B prevention.

\section{Literature Review}

The objectives of this study had been evaluated after knowing the knowledge and attitude of people at community therefore the literature had been divided into two sections to support each of study's variables with different literature review.

\section{Knowledge}

The study revealed after examination of knowledge of every individual in a rural area Quetta Pakistan, with respect to Hepatitis-B prevention and its mode of transmission which could bring an attentive and thoughtful moment for individuals (Hassali, 2012). The study had been finished in Quetta Pakistan, so the Knowledge was poor among people with respect to Hepatitis-B prevention which was a concerning point because a little rate of respondents knew about Hepatitis-B prevention and transmission which may be a deadly condition for Quetta 
inhabitants in Pakistan (Farooqui, 2012). Just twenty eight percent of the member comprehended that Hepatitis-B can bring about liver tumor and other complications related to hepatitis B, that is another alarming edge for people (Haq et al., 2012).

Moreover, another study which uncovered the poor knowledge among the people of rural area in Iraq having knowledge about HBV is comparatively poor, with important thing which need to be completed in term of awareness e.g. public awareness and immunization attention, mainly among people, which are essential to decrease problem of the disease (Hepatitis B) through further research needs to be explored the reasons behind such poor knowledge in a more in-depth manner."(Samir, 2013).

Furthermore, there was another study which was completed in Ethiopia among medical students highlighted that, poor knowledge toward hepatitis $\mathrm{B}$, its prevention and its mode of transmission make them vulnerable to enter into medical profession, because according to this study ninety five percent student have still no knowledge regarding immunization of Hepatitis-B (Mesfin et al. 2013).

\section{Attitude}

The study exposed that almost community people was in predisposition for making free evaluations for their Health status and were preferring specific behavior for wellbeing e.g. concerning with (profound healers, yunani, Ayurveda and homeopathic recovering contexts) bring therapeutic variety in their mind (Saleem et al., 2012). In contrast poverty and social beliefs among them greatly influence their health such as the disease further lead to adverse condition which then unable to control (Shafie et al., 2012). The inhabitants were agreed upon to heal the disease through these centers instead of medical treatment and immunization to prevent Hepatitis-B permanently, even their attitude were fixed on these healers because they believed that Hepatitis-B treatment is irrational (Haq et al. 2012), another element is poverty and high expense of treatment which compels them toward treatment from these centers rather than restorative health centers such as hospitals or medical centers in that region (Haq, 2012).

Mostly people believed that if the immunization against Hepatitis-B virus had been done, then there is much more possibilities to detect the virus in the blood after screening even immunized. As a study which was completed on behavior and attitude toward immunization of Hepatitis-B found that people feared from immunization, they believed that Hepatitis-B virus will be detected in their blood after screening if they immunized, so due to this reason they were not immunized against Hepatitis-B.
According to a study on attitude of people toward vaccination, find out that it is an individual responsibility to take or obtain vaccination against Hepatitis-B, especially occupational health doctors and nurses whereby they are consistently interact with Hepatitis-B affected patients and much more, so every medical profession personals must take vaccination and modify their attitude toward vaccination because when they modify their attitude toward vaccination, they can be easily convinced the other to adapt such attitude. The indicating sign to get infection is interlinked with resources of a given society, knowledge of people toward infection, behavior toward treatment and prevention of Hepatitis-B what people do and act. This lack of few factors which must need for the society to act upon, who deserve in given context (Gunson et al., 2003)

\section{Methodology}

A descriptive, quantitative cross-sectional study was designed for this research study to determine knowledge and attitudes regarding Hepatitis-B prevention among people of Lahore community. By engaging convenience sampling method, the target population was 400 in which 200 respondents were taken as a sample size according to slovin, s formula $\mathbf{n}=\mathbf{N} / \mathbf{1}+(\mathbf{N})(\mathbf{E})^{\mathbf{2}}$ for this study.

The participants of this study were selected through convenient method in which healthy persons of Ali Raza Abad community aging between 20 and 40 years, with no physical and mental disorder, not using any type of medication, and familiarity with Urdu (National language of Pakistan) were included in the study. A selfadministered questionnaire using likert scale (Strongly Disagree $=1$ to Strongly Agree=5) were used to collect information which was divided into three sections, section (A) covered the socio-demographic characteristics of respondents, section (B) covered the knowledge towards transmission and prevention method of Hepatitis-B virus and section $(\mathrm{C})$ covered the attitude towards prevention of HBV. Enough information of research was provided to participants with the help of full consent form and this was achieved via a consent letter attached to the questionnaire. Confidentiality was considered by informing participants.

The tool for this study was a self-reported questionnaire, in which the knowledge questionnaire was adapted from an article written by (Abdal et al., 2013). The Attitude questionnaire was also measured by likert scale which was adapted from an article written by (Khiruddin et al., 2015) were distributed among people of Lahore community. The collected data were analyzed by putting data on SPSS version 21. After completion of data collection, data had been coded, captured on Excel and then was imported into the statistical Package for Social Sciences (SPSS) version 21.0 for Descriptive analysis and statistics. 


\section{Results}

\section{Section A: Demographic Analysis}

\section{Gender}

Data was collected from both genders. Table 1 show that the male respondents were $120(60 \%)$ and the female respondents were $80(40 \%)$.

Table 1: Gender of respondents

\begin{tabular}{|l|l|l|}
\hline Gender & Frequency & Percentage \\
\hline Male & 120 & 60.0 \\
\hline Female & 80 & 40.0 \\
\hline Total & 200 & 100.0 \\
\hline
\end{tabular}

\section{Age Group}

The whole proportion of sample size comprised on male and female in Lahore community. Table .2 illustrates that $41(20.5 \%)$ of the respondents were 21 to 25 years old, 74 (37\%) between 26 to 30 years of age, 55 (27.5\%) were between 31 to 35 years age, and 30 (15\%) were between 36 to 40 years of age.

Table 2: Age group of respondents

\begin{tabular}{|l|l|l|}
\hline Age group & Frequency & Percentage \\
\hline $21-25$ & 41 & 20.5 \\
\hline $26-30$ & 74 & 37.0 \\
\hline $31-35$ & 55 & 27.5 \\
\hline $36-40$ & 30 & 15.0 \\
\hline Total & 200 & 100.0 \\
\hline
\end{tabular}

\section{Qualification}

Table 3 mention that most of the respondents were at primary level education 90 (45\%), and the 60 (30\%) were at matric level and contrast to this 50 (25\%) were categorized in others.

Table 3: Qualification of respondents

\begin{tabular}{|l|l|l|}
\hline Qualification & Frequency & Percentage \\
\hline Primary & 90 & 45.0 \\
\hline Matric & 60 & 30.0 \\
\hline Other & 50 & 25.0 \\
\hline Total & 200 & 100.0 \\
\hline
\end{tabular}

\section{Section B: Analysis of Questions (Knowledge)}

Question 1: Is Hepatitis-B contagious?

The study was completed in a community of Lahore Pakistan, in which 200 participants were included. Table no. 4 reveals that out of these 200 participants, $13(1.5 \%)$ were strongly disagree, $26(13 \%)$ were disagree, $32(16 \%)$ were neutral, $110(55 \%)$ respondents were agree, and $29(14.5 \%)$ were strongly agree about the question.

Table 4: Is Hepatitis-B contagious?

\begin{tabular}{|l|l|l|}
\hline Is Hepatitis-B contagious? & Frequency & Percentage \\
\hline Strongly disagree & 3 & 1.5 \\
\hline Disagree & 26 & 13.0 \\
\hline Neutral & 32 & 16.0 \\
\hline Agree & 110 & 55.0 \\
\hline Strongly agree & 29 & 14.5 \\
\hline Total & 200 & 100.0 \\
\hline
\end{tabular}

\section{Question 2: Can Hepatitis-B be lethal?}

Table 5 shows response of the participants to the second question in which 6(3\%) were strongly disagree, $20(10 \%)$ were disagree, 37(18.5\%) were neutral, 59(29\%) were agree, and 78(39\%) respondents were strongly agree about the question. The response of question shows that most the people knew that Hepatitis-B can lead to death but some of them did not know.

Table 5: Can Hepatitis-B be lethal?

\begin{tabular}{|l|l|l|}
\hline Can Hepatitis-B be lethal? & Frequency & Percentage \\
\hline Strongly disagree & 6 & 3.0 \\
\hline Disagree & 20 & 10.0 \\
\hline Neutral & 37 & 18.5 \\
\hline Agree & 59 & 29.5 \\
\hline Strongly agree & 78 & 39.0 \\
\hline Total & 200 & 100.0 \\
\hline
\end{tabular}

\section{Question 3: Can Vaccination protect against Hepatitis-B infection.}

Table 6 reveals about vaccination in which the respondents $14(7 \%)$ were strongly disagree, $17(8.5 \%)$ were disagree, $24(12 \%)$ were neutral, $90(45 \%)$ were agree and 55 $(27.5 \%)$ were strongly agree accordingly. The knowledge regarding vaccination was almost good but among these 
respondents (including male and female) $24+17=(41)$ people were unaware about Hepatitis-B vaccination.

Table 6: Can vaccination protect against Hepatitis-B infection?

\begin{tabular}{|l|l|l|}
\hline $\begin{array}{l}\text { Can vaccination protect } \\
\text { against Hepatitis-B } \\
\text { infection? }\end{array}$ & Frequency & Percentage \\
\hline Strongly disagree & 14 & 7.0 \\
\hline Disagree & 17 & 8.5 \\
\hline Neutral & 24 & 12.0 \\
\hline Agree & 90 & 45.0 \\
\hline Strongly agree & 55 & 27.5 \\
\hline Total & 200 & 100.0 \\
\hline
\end{tabular}

Question 4: Can vaccination protect sexual partner from Hepatitis-B infection?

Table 7 mention that 2(1\%) participants were strongly disagree, $8(4 \%)$ were disagree, 26(13\%) were neutral, $89(44.5 \%)$ were agreed and $75(37.5 \%)$ were strongly agree.

Table 7: Can vaccination protect sexual partner from Hepatitis-B infection?

\begin{tabular}{|l|l|l|}
\hline $\begin{array}{l}\text { Can vaccination protect } \\
\text { sexual partner from } \\
\text { Hepatitis-B infection? }\end{array}$ & Frequency & Percentage \\
\hline Strongly disagree & 2 & 1.0 \\
\hline Disagree & 8 & 4.0 \\
\hline Neutral & 26 & 13.0 \\
\hline Agree & 89 & 44.5 \\
\hline Strongly agree & 75 & 37.5 \\
\hline Total & 200 & 100.0 \\
\hline
\end{tabular}

\section{Question 5: Can Hepatitis-B vaccination cause} unpleasant side effects?

Table 8 illustrate that out of 200 respondents 5(2.5\%) were strongly disagree, $36(18 \%)$ respond totally disagree, $27(13.5 \%)$ were neutral, $60(30 \%)$ were agree and $72(36 \%)$ were strongly agree. 132/200 respondents had positive response, which shows that still the people (including males and females) had misconception about Hepatitis-B vaccination and its side effects which showed poor knowledge.

\section{Question 6: Does everyone need Hepatitis-B} vaccination?

Table 9 is capturing about vaccination in which the responses are $7(3.5 \%)$ were totally strongly disagree,
$19(9.5 \%)$ were disagree, $27(13.5 \%)$ were neutral, $106(53 \%)$ were agree, and 41(20\%) were strongly agree

Table 8: Can Hepatitis-B vaccination cause unpleasant side effects?

\begin{tabular}{|l|c|c|}
\hline $\begin{array}{l}\text { Can Hepatitis-B vaccination } \\
\text { cause unpleasant side } \\
\text { effects? }\end{array}$ & Frequency & Percentage \\
\hline Strongly disagree & 5 & 2.5 \\
\hline Disagree & 36 & 18.0 \\
\hline Neutral & 27 & 13.5 \\
\hline Agree & 60 & 30.0 \\
\hline Strongly agree & 72 & 36.0 \\
\hline Total & 200 & 100.0 \\
\hline
\end{tabular}

Table 9: Do everyone needs Hepatitis-B vaccination?

\begin{tabular}{|l|l|l|}
\hline $\begin{array}{l}\text { Does everyone need } \\
\text { Hepatitis-B vaccination? }\end{array}$ & Frequency & Percentage \\
\hline Strongly disagree & 7 & 3.5 \\
\hline Disagree & 19 & 9.5 \\
\hline Neutral & 27 & 13.5 \\
\hline Agree & 106 & 53.0 \\
\hline Strongly agree & 41 & 20.5 \\
\hline Total & 200 & 100.0 \\
\hline
\end{tabular}

\section{Question 7: Are the costs for Hepatitis-B vaccination unaffordable for male \& female?}

Table 10 describes about the vaccination and its cost, in which most of respondents showed responses in which $8(4 \%)$ were totally strongly disagree, 24 (12\%) were disagree, 23 (11.5\%) were neutral, 106 (53\%) were agree and $39(19.5 \%)$ were strong agree respectively.

Table 10: Are the costs for Hepatitis-B vaccination unaffordable for male \& female?

\begin{tabular}{|l|l|l|}
\hline $\begin{array}{l}\text { Are the costs for Hepatitis-B } \\
\text { vaccination unaffordable for } \\
\text { male \& female? }\end{array}$ & Frequency & Percentage \\
\hline Strongly disagree & 8 & 4.0 \\
\hline Disagree & 24 & 12.0 \\
\hline Neutral & 23 & 11.5 \\
\hline Agree & 106 & 53.0 \\
\hline Strongly agree & 39 & 19.5 \\
\hline Total & 200 & 100.0 \\
\hline
\end{tabular}

Based on the data collected for responses of knowledge of respondents, the summarized data is given in Table 11 
Table 11: Summary of Frequency distribution table of participants' response on Knowledge

\begin{tabular}{|c|c|c|c|c|c|c|}
\hline S.N. & Questions & $\begin{array}{l}\text { Strongly } \\
\text { disagree } \\
\mathrm{F}(\%)\end{array}$ & $\begin{array}{l}\text { Disagree } \\
\mathrm{F}(\%)\end{array}$ & $\begin{array}{l}\text { Neutral } \\
F(\%)\end{array}$ & $\begin{array}{l}\text { Agree } \\
\text { F (\%) }\end{array}$ & $\begin{array}{l}\text { Strongly } \\
\text { agree } \\
\text { F }(\%)\end{array}$ \\
\hline 1 & Is Hepatitis-B contagious? & $3(1.5)$ & $26(13)$ & $32(16)$ & $110(55)$ & $29(14.5)$ \\
\hline 2 & Can Hepatitis-B be lethal? & $6(3)$ & $20(10)$ & $37(18.5)$ & $59(29.5)$ & $78(39)$ \\
\hline 3 & $\begin{array}{l}\text { Can vaccination protect against Hepatitis-B } \\
\text { infection? }\end{array}$ & $14(7)$ & $17(8.5)$ & $24(12)$ & $90(45)$ & $55(27.5)$ \\
\hline 4 & $\begin{array}{l}\text { Can vaccination protect sexual partner from } \\
\text { Hepatitis-B infection? }\end{array}$ & $2(1)$ & $8(4)$ & $26(13)$ & $89(44.5)$ & $75(37.5)$ \\
\hline 5 & $\begin{array}{l}\text { Can Hepatitis-B vaccination cause unpleasant side } \\
\text { effects? }\end{array}$ & $5(2.5)$ & $36(18)$ & $27(13.5)$ & $60(30)$ & $72(36)$ \\
\hline 6 & Does everyone need Hepatitis-B vaccination? & $7(3.5)$ & $19(9.5)$ & $27(13.5)$ & $106(53)$ & $41(20)$ \\
\hline 7 & $\begin{array}{l}\text { Are the costs for Hepatitis-B vaccination } \\
\text { unaffordable for male \& female? }\end{array}$ & $8(4)$ & $24(12)$ & $23(11.5)$ & $106(53)$ & $39(19.5)$ \\
\hline
\end{tabular}

\section{Questions on Attitude}

\section{Question 8: Can Hepatitis-B be transmitted by un- sterilized syringes, needles and surgical instruments?}

Table 12 showed the responses of 200 respondents regarding attitude toward Hepatitis-B prevention. All the statements were about attitude what they believe, feel or act in particular situation when they heard about hepatitis $\mathrm{B}$, so out of 200 respondents the first statement was about transmission of Hepatitis-B infection in which $9(4.5 \%)$ were strongly disagree, $19(9.5 \%)$ were disagree, $31(15.5 \%)$ were neutral $97(48.5 \%)$ were agree and $4(22 \%)$ were strongly agree.

Table 12: Can Hepatitis-B be transmitted by un-sterilized syringes, needles and surgical instruments?

\begin{tabular}{|l|c|c|}
\hline Can Hepatitis-B be & Frequency & Percentage \\
transmitted by un-sterilized & & \\
syringes, needles and & & \\
surgical instruments? & 9 & 4.5 \\
\hline Strongly disagree & 19 & 9.5 \\
\hline Disagree & 31 & 15.5 \\
\hline Neutral & 97 & 48.5 \\
\hline Agree & 44 & 22.0 \\
\hline Strongly agree & 200 & 100.0 \\
\hline Total & & \\
\hline
\end{tabular}

\section{Question 9: Is Vaccine available for Hepatitis-B?}

Table 13 described the attitude in which $24(12 \%)$ were strongly agree, $20(10 \%)$ were disagree, $43(21.5 \%)$ were neutral, 77(38.5\%) were agree, 36(18\%) were strongly agree. Total numbers of negative responses were $44(22 \%)$.

Table 13: Is vaccine available for Hepatitis-B?

\begin{tabular}{|l|c|c|}
\hline $\begin{array}{l}\text { Is vaccine available for } \\
\text { Hepatitis-B? }\end{array}$ & Frequency & Percentage \\
\hline Strongly disagree & 24 & 12.0 \\
\hline Disagree & 20 & 10.0 \\
\hline Neutral & 43 & 21.5 \\
\hline Agree & 77 & 38.5 \\
\hline Strongly agree & 36 & 18.0 \\
\hline Total & 200 & 100.0 \\
\hline
\end{tabular}

Question 10: If you think that you have symptoms of Hepatitis-B, then, is it better to concern with spiritual healers, homeopathic or hakeem?

Table 14 showed the attitude of the 200 respondents, in which $12(6 \%)$ were strongly disagree, $16(8 \%)$ were disagree, $83(41.5 \%)$ were strongly agree, 14 (7\%) were neutral, 75 (37.5\%) were agree and 83 (41.5\%) were strongly agree.

\section{Question 11: Can sharing of food/utensils/water also cause Hepatitis-B with others?}

Table . 15 captured about Sharing of utensils, affected person's food and water can lead to get Hepatitis-B responses, in which total number of respondents were 200, out of them $4(2 \%)$ were strongly disagree, $23(11.5 \%)$ were disagree, 41(20.5\%) were neutral, 92(46\%) were agree, $40(20 \%)$ were strongly agree. 
Table 14: If you think that you have symptoms of Hepatitis-B, then, is it better to concern with spiritual healers, homeopathic or hakeem?

\begin{tabular}{|l|c|c|}
\hline $\begin{array}{l}\text { If you think that you have } \\
\text { symptoms of Hepatitis-B, } \\
\text { then, is it better to concern } \\
\text { with spiritual healers, } \\
\text { homeopathic or hakeem? }\end{array}$ & Frequency & Percentage \\
\hline Strongly disagree & 12 & 6.0 \\
\hline Disagree & 16 & 8.0 \\
\hline Neutral & 14 & 7.0 \\
\hline Agree & 75 & 37.5 \\
\hline Strongly agree & 83 & 41.5 \\
\hline Total & 200 & 100.0 \\
\hline
\end{tabular}

Table 15: Can sharing of food/utensils/water also cause Hepatitis-B with others?

\begin{tabular}{|l|l|l|}
\hline $\begin{array}{l}\text { Can sharing of } \\
\text { food/utensils/water also } \\
\text { cause Hepatitis-B with } \\
\text { others? }\end{array}$ & Frequency & Percentage \\
\hline Strongly disagree & 4 & \\
\hline Disagree & 23 & 2.0 \\
\hline Neutral & 41 & 20.5 \\
\hline Agree & 92 & 46.0 \\
\hline Strongly agree & 40 & 20.0 \\
\hline Total & 200 & 100.0 \\
\hline
\end{tabular}

Question 12: After symptoms appearance of Hepatitis-B, is it better to prefer complementary therapy as compared to medical treatment?

Table 16 stated the attitude of people, what they believe regarding Hepatitis-B treatment and prevention. Furthermore their responses were $5(2.5 \%)$ were strongly disagree, $18(9 \%)$ were disagree, 21(10.5\%) were neutral, $94(47 \%)$ were agree and $40(20 \%)$ were strongly agree accordingly.

\section{Question 13: Does the treatment against the Hepatitis-B should be continued and completed?}

Table 17 shows the frequency and percentage of 200 respondents regarding treatment completion of Hepatitis-B infection, in which $10(5 \%)$ were strongly disagree, $16(8 \%)$ were disagree, $65(32 \%)$ were neutral, 63(31\%) were agree, and $46(23 \%)$ were strongly agree simultaneously.

Table 16: After symptoms appearance of Hepatitis-B, is it better to prefer complementary therapy as compared to medical treatment?

\begin{tabular}{|l|c|c|}
\hline $\begin{array}{l}\text { After symptoms } \\
\text { appearance of Hepatitis-B, }\end{array}$ & Frequency & Percentage \\
$\begin{array}{l}\text { is it better to prefer } \\
\text { complementary therapy as } \\
\text { compared to medical } \\
\text { treatment? }\end{array}$ & & \\
\hline Strongly disagree & 5 & \\
\hline Disagree & 18 & 2.5 \\
\hline Neutral & 21 & 10.5 \\
\hline Agree & 94 & 47.0 \\
\hline Strongly agree & 62 & 31.0 \\
\hline Total & 200 & 100.0 \\
\hline
\end{tabular}

Table 17: Does the treatment against the Hepatitis-B should be continued and completed?

\begin{tabular}{|l|l|l|}
\hline $\begin{array}{l}\text { Does the treatment against } \\
\text { the Hepatitis-B should be } \\
\text { continued and completed? }\end{array}$ & Frequency & Percentage \\
\hline Strongly disagree & 10 & 5.0 \\
\hline Disagree & 16 & 8.0 \\
\hline Neutral & 65 & 32.5 \\
\hline Agree & 63 & 31.5 \\
\hline Strongly agree & 46 & 23.0 \\
\hline Total & 200 & 100.0 \\
\hline
\end{tabular}

Question 14: Is HBV vaccination not for all people?

Table 18 describes the attitude of respondents in which $31(15.5 \%)$ were strongly disagree, $85(42 \%)$ disagree, $56(8 \%)$ were neutral, $16(8 \%)$ were agree and only $12(\%)$ were strongly agree.

Table 18: Is HBV vaccination not for all people?

\begin{tabular}{|l|l|l|}
\hline $\begin{array}{l}\text { Is HBV vaccination not for } \\
\text { all people? }\end{array}$ & Frequency & Percentage \\
\hline Strongly disagree & 31 & 15.5 \\
\hline Disagree & 85 & 42.5 \\
\hline Neutral & 56 & 28.0 \\
\hline Agree & 16 & 8.0 \\
\hline Strongly agree & 12 & 6.0 \\
\hline Total & 200 & 100.0 \\
\hline
\end{tabular}

Data achieve for attitude from Table 12 to 18 has been summarized in Table 19 
Table 19: Summary of Frequency distribution table of participants' response on Attitude

\begin{tabular}{|c|c|c|c|c|c|c|}
\hline S.N. & Questions & $\begin{array}{l}\text { Strongly } \\
\text { disagree } \\
\text { F }(\%)\end{array}$ & $\begin{array}{l}\text { Disagree } \\
\text { F }(\%)\end{array}$ & $\begin{array}{l}\text { Neutral } \\
\text { F }(\%)\end{array}$ & $\begin{array}{l}\text { Agree } \\
\text { F (\%) }\end{array}$ & $\begin{array}{l}\text { Strongly } \\
\text { agree } \\
\text { F }(\%)\end{array}$ \\
\hline 1 & $\begin{array}{l}\text { Can Hepatitis-B be transmitted by un-sterilized } \\
\text { syringes, needles and surgical instruments? }\end{array}$ & $9(4.5)$ & $19(9.5)$ & $31(15.5)$ & $97(48.5)$ & $44(22)$ \\
\hline 2 & Is vaccine available for Hepatitis-B? & $24(12)$ & $20(10)$ & $43(21.5)$ & $77(38.5)$ & $36(18)$ \\
\hline 3 & $\begin{array}{l}\text { If you think that you have symptoms of Hepatitis-B, } \\
\text { then, is it better to concern with spiritual healers, } \\
\text { homeopathic or hakeem? }\end{array}$ & $12(6)$ & $16(8)$ & $14(7)$ & $75(37.5)$ & $83(41.5)$ \\
\hline 4 & $\begin{array}{l}\text { Can sharing of food/utensils/water also cause Hepatitis- } \\
\text { B with others? }\end{array}$ & $4(2)$ & $23(11.5)$ & $41(20.5)$ & $92(46)$ & $40(20)$ \\
\hline 5 & $\begin{array}{l}\text { After symptoms appearance of Hepatitis-B, is it better } \\
\text { to prefer complementary therapy as compared to } \\
\text { medical treatment? }\end{array}$ & $5(2.5)$ & $18(9)$ & $21(10.5)$ & $94(47)$ & $62(31)$ \\
\hline 6 & $\begin{array}{l}\text { Does the treatment against the Hepatitis-B should be } \\
\text { continued and completed? }\end{array}$ & $10(5)$ & $16(8)$ & $65(32)$ & $63(31)$ & $46(23)$ \\
\hline 7 & Is $\mathrm{HBV}$ vaccination not for all people? & $31(15.5)$ & $85(42.5)$ & $56(28)$ & $16(8)$ & $12(6)$ \\
\hline
\end{tabular}

\section{Discussion}

The current cross-sectional study sought out the score of knowledge included 200 people including male and female aging between 20-40 years from the community of Lahore Ali Raza Abad. The aim of the study was to determine the knowledge and attitude regarding Hepatitis-B prevention among people. According to this study, almost people had misconception about preventive measure like vaccination as responses of people showed, toward vaccination in which 14 (7\%), 17 (8.5\%), 2(1\%), 8(4\%), 5(2.5\%), 36 $(18 \%)$ respectively were completely unaware from vaccination which is a concerning point for community's people.

Soad et al. (2012) stated in their similar study that level of knowledge toward infection, routes of transmission and its preventive measures, in which people have good knowledge regarding Hepatitis-B infection but they have very low level of knowledge toward vaccination and infection in which $(81.5 \%)$ people did not interpret the significant association of knowledge about vaccination and Hepatitis-B infection.

In addition the attitude of people shows toward Hepatitis$B$ prevention and medical treatment found that most of the respondents considered that Hepatitis-B treatment should not continuo until its sign and symptoms appeared. The responses of the people indicated in this study regarding attitude toward prevention of Hepatitis-B in which 12 $(6 \%), 16(8 \%), 5(2.5 \%), 18(9 \%)$ people were prefer to concern with irrelevant treatment like spiritual healers and homeopathic etc. Furthermore people had misconception about vaccination and had negative attitude toward vaccination in which $31(15.5 \%)$ and 85 (42.5\%) people even did not know about vaccination that there is vaccine for hepatitis B. They had their own concept regarding treatment like they were preferred spiritual healers mostly; moreover another factor is poverty and cultural belief which influence them toward this type of treatment.

According to a study which was conducted by Nomanul Haq, 2012 in Pakistan on attitude that majority of the participants stated to use complementary and alternative medicines if infected with Hepatitis B. Home remedies, herbal and traditional therapies were the treatment of choice until there is no improvement in the sign and symptoms of infection. Consulting the physicians was sought as the last option among those people.

\section{Conclusion}

The study had been determined the knowledge and attitude of people regarding Hepatitis-B prevention, in which vaccination was very important preventive measure against Hepatitis B. The level of knowledge was good among people but there was no significant association between vaccination and Hepatitis-B infection among the people as the results showed that Hepatitis-B vaccination has side effects, it was just rumors in that community because there were cultural belief exist which greatly influence their knowledge.

Moreover they believed that home remedies complementary therapies and spiritual healers were preferred as compared to medical treatment. Furthermore factors (poverty, social context and conviction) were also influencing their conception toward Hepatitis-B prevention (vaccination).

\section{Recommendations}

$\checkmark$ The stack holders of the community, government/institutes and NGO, s must develop strategies to uphold vaccination campaign in the community. 
$\checkmark$ Furthermore strategies to sponsor health care organizations in such a way with a resultant change of their behavior.

$\checkmark$ Health education programme and further study need to be explored holistically to reduce the gaps between their belief and medical treatment against Hepatitis-B infection which is a fatal disease around the globe.

\section{References}

Ali M, Idrees M, Ali L, Hussain A, Rehman IU, Saleem S and Butt S (2011) Hepatitis-B virus in Pakistan: a systematic review of prevalence, risk factors, awareness status and genotypes. Virology journal 8(1): 1 .

Abdal M, Al-Mousa K and Joseph B (2013). Knowledge, Attitude, and Practice of HBV vaccination among dentists in primary health care, dental centers and Kuwait university dental clinics (KUDCs).

Bello CS, Opajobi SO, Okolo SN, Olarewaju RS, and Idoko LO (1992) Hepatitis-Bvirinfection in sexually transmitted disease clinic attenders in an African city (Jos, Nigeria). Genitourinary medicine 68(5): 342.

Carabez RM, Swanner JA, Yoo GJ, and Ho M (2014) Knowledge and fears among Asian Americans chronically infected with Hepatitis-B. Journal of Cancer Education 29(3): 522-528.

Chang MH (2007) Hepatitis- $B$ virus infection. In: Seminars in fetal and neonatal medicine (Vol. 12, No. 3, pp. 160167). WB Saunders.

Gourley SA, Kuang Y, and Nagy JD (2008) Dynamics of a delay differential equation model of Hepatitis- $B$ virus infection. Journal of Biological Dynamics 2(2): 140153.

Gunson RN, Shouval D, Roggendorf M, Zaaijer H, Nicholas H, Holzmann H, and Marinho RT et al. (2003) Hepatitis-B virus (HBV) and Hepatitis-C virus (HCV) infections in health care workers ( $H C W s)$ : guidelines for prevention of transmission of $\mathrm{HBV}$ and $\mathrm{HCV}$ from $\mathrm{HCW}$ to patients. Journal of Clinical Virology 27(3): 213-230.

Haq N, HassaliMA, ShafieAA, SaleemF, and AljadheyH(2012)A cross sectional assessment of health related quality of life among patients with Hepatitis-B in Pakistan. Health and quality of life outcomes, 10(1), 1.

Khiruddin AI, Afriandi I, Aznur L and Setiawati EP (2015). Intention for Hepatitis-B Vaccination among Male-tofemale Transgenders in Bandung. Althea Medical Journal 2(2): 253-261.
Kumar A, Lalani S, Afridi AAK, and Khuwaja AK (2010) Screening of Hepatitis- $B$ and $C$ among people visiting general practice clinics in a rural district of Sindh, Pakistan. J Ayub Med Coll Abbottabad 22(4)

LaunialaA(2009)How much can a KAP survey tell us about people's knowledge, attitudes and practices, some observations from medical anthropology research on malaria in pregnancy in Malawi. Anthropology Matters 11(1).

McCarthy GM (2000) Risk of transmission of viruses in the dental office. J Can Dent Assoc. 66(10): 554-557.

McGraneJ and StainesA(2003)Nursing staff knowledge of the Hepatitis- $B$ virus including attitudes and acceptance of Hepatitis- $B$ vaccination: development of an effective program. AAOHNjournal: official journal of the American Association of Occupational Health Nurses, 51(8): 347-352.

Mesfin YM and Kibret KT (2013) Assessment of knowledge and practice towards Hepatitis-B among medical and health science students in Haramaya University, Ethiopia. PloS One 8(11): e79642.

Othman SM, Saleh AM, and Shabila NP (2013) Knowledge about Hepatitis-B Infection among Medical Students in Erbil City, Iraq. European Scientific Journal.

Ozaras R and Tahan V (2009) Acute hepatitis C: prevention and treatment. Expert review of anti-infective therapy 7(3): 351-361.

Saleem F, Hassali MA, Shafie AA, Awad AG and Bashir S (2011) Association between knowledge and drug adherence in patients with hypertension in Quetta, Pakistan. Tropical Journal of Pharmaceutical Research 10(2).

Satekge MM (2012) Knowledge, Attitudes and Practices regarding the Prevention of Hepatitis- $B$ Viurs Infections, in Final Year College Student Nurses in Gauteng Province.

Singhal V, Bora D, and SinghS (2009) Hepatitis-B in health care workers: Indian scenario. Journal of laboratory physicians, 1(2), 41.

Soad A, Habiba, Ghadeer AA and lrashidi et.al (2012) Knowledge, attitude and behavior of health care workers regarding Hepatitis- $B$ infection in primary health care, Kuwait. Greener Journal of Medical Sciences. 2(4): 077-083.

WHO (World Health Organization) (2008) Advocacy, communication and social mobilization for TB control: a guide to developing knowledge, attitude and practice surveys. 